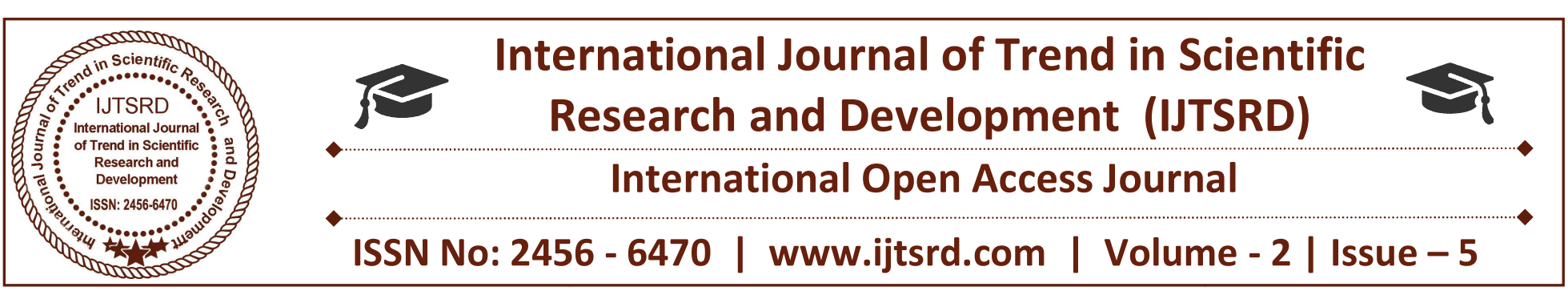

\title{
Indian Economy in the Past and its Current Situation in Current World
}

\author{
Anushri Pandey \\ B.B.A, L.L.B.(hons), Indore Institute of Law, \\ Indore, Madhya Pradesh, India
}

\begin{abstract}
The Economy of India is a developing economy. It is the world's seventh-largest economy by GDP and the third largest by purchasing power parity (PPP). India is the fastest growing economy in the world. India's economic success in recent years has helped to ensure south Asia is the fastest growing region in the world. India is developing into an open-market economy.

" PV NARASIMHA RAO" Remembered as father of Indian economy. To understand the present level of the Indian economy, it is important to understand the economic system of India during the British rule and post-independence economic development policies. Before the advent of British rule, India had an independent economy. It was largely primary sector economy and the major occupations were agriculture, handicrafts, and many other primary sector works. The economy was full of resources and a prosperous one. Therefore, high quality agricultural products and handicrafts made by the Indians were traded across the world.
\end{abstract}

\section{INTRODUCTION}

The economic development in India followed socialist-inspired people for most of its independent history as we all know that our Indian economy is developing day by day new schemes are launched Modi made so many changes. In last 3 years INR has improved or remained stable. When BJP government took office it was falling very badly. The modi government is known for their bold and quick decision they taken many bold decision in short time and somewhere these moves have caused a temporary slowdown in the economy. The surplus income of India was used in setting up the official infrastructure for the British officers. During the British period, some of the infrastructures such as road, rail, telegraph, ports, water transport, etc. were developed, but all these were developed not for the benefit of Indians, but, rather to serve the interests of British official

\section{ECONOMIC POLICIES POST INDEPENDENCE:}

The post independence period of India was marked by economic policies which tried to make country self sufficient. New roads were built, dams and electricity was spread to the rural areas to improve the standard of living.

The economy started showing recovery in the early 1990s when government adopted new economic model known as Liberalisation, Privatisation, Globalisation.

The major problems were:

Drought,

"Flood,

$>$ Poor irrigation system,

$>$ Desalination of soil,

Absence of technology, and

Poverty.

India did not undergo any industrialization as all the raw materials were exported to the UK. Handicrafts and other small-scale industries suffered badly. The main intention of British rule was to make India, a market of their finished products. In India, many industries developed even in the time of crisis. For example, the jute industry in West Bengal and the cotton textile industry in regions of Gujarat and Maharashtra.On 15 June, 1947 the British House of Commons passed the Indian independence act, which

Divided India into two parts India and Pakistan. India has been under British control since the $18^{\text {th }}$ 
century.The history of republic of India begins on 26 January 1950 the country became an independent nation.

\section{ECONOMIC REFORMS DURING 1960s to 1980s :}

During the 1960s a higher growth was achieved and 'pre-conditions for takeoff' became visible. But the country experienced three twos during 1960s:

1. Deaths of two prime ministers (Jawaharlal Nehru and Lalbahadur Sashtri)

2. Two wars with China (1962) and Pakistan (1965), and

3. Two droughts in 1965 and 1966.

The crisis was so grave that the country had to import large amount of food grains from other countries - a condition known as 'ship to mouth'. The INDIAN economy then made a retrograde journey.

The 1970s was called the 'decade of change' or 'reform by stealth'. In the 1970s, Indira Gandhi found that the brand of socialism initiated by her father had resulted in some social conflicts. During her initial stewardship, we saw some conflicts between government and private industrialists.

She took up some anti-rich policies like, abolition of princely states, bank nationalization, and implementation of MRTP (Monopolies and Restrictive Trade Practices) provisions to curb the growth of large monopoly houses, nationalization of coal industry, and many anti-poverty measures. Signs of pitfalls in our economic policies were raising their ugly heads and the need for reforms became uppermost in the minds of the policymakers'. However, the economic and political climate was not propitious for reforms since the mindset of the Indian leaders and policymakers was still pro-government.

The growth scenario that we saw during 1951-1979 was rather discouraging. As real GDP grew at an annual rate of around 3.5 p.c. during 1951 and until 1980, Raj Krishna christened this economic performance as 'Hindu rate of growth' a syndrome that continued for almost 30 years. During 1980, China and India had been ranked as the 19th and the 20th largest economic power in the world. And, it was believed that such growth rate was 'inevitable'. But why?
2. 1980S AND STRUCTURAL PROBLEMS:

During her last phase of life in the early 1980s, Indira Gandhi continued her tirade against private sector banks. She nationalized 6 more banks and attempted to further liberalize the Indian economy more. One could see then raising of the exemption limit from licensing, relaxations to MRTP (Monopolies and Restrictive Trade Practices) and FERA (Foreign Exchange Regulation Act) companies, deli censing, etc., to woo private investors. Meanwhile, her assassination in 1984 upset all economic calculations.

One thing clear from such economic policies pursued then is that the country had been moving more towards capitalist path of development - a deviation from Nehru's so- called socialistic path of development often called Nehruvian socialism.

\section{OUTCOMES OF FAULTY ECONOMIC POLICIES:}

To understand the dynamics of economic reforms, one must have some knowledge about the economic policies pursued during 1951- 1991. Development goals of the country consisted of higher economic growth, social justice, poverty eradication, selfreliance.

To achieve these goals, our institutional structure cent red on the mixed economy principle where both public and private sectors functioned with their distinctive roles. Economic activities were carried through planning mechanism with less emphasis on market mechanism. Development strategy of this time came to be known as 'inward-looking strategy'. This strategy consisted of controls and regulations of the economy through industrial licenses and import controls

\section{IMPACT OF GLOBAL FINANCIAL MELTDOWN OF 2008 -2009 ON INDIAN ECONOMY: POSITIVE IMPACTS OF GLOBAL FINANCIAL CRISIS ON INDIAN ECONOMY}

\section{Emergence of a new economy}

This is the time of global financial crisis when world's biggest economies like US and Europe are struggling to overcome this situation and India was able to invest money for launching of chandrayaan-1.This is the time when world's most powerful economies are suffering more than Indian economy. This crisis has affected developed country economies more than developing country's economy. In USA huge giants of banking and finance sector like Lehman Brothers, 
Merrill Lynch, Washington Mutual Operations etc. could not survive in this crisis and have lost their existence. In comparison to such horrible conditions India is in a better place. It is an appreciating fact that we have a number of companies still reporting successes at this time. Some of the businesses have diversified into a number of areas and others have exposure to export markets.

\section{Expose of weaknesses in the economy}

The major role of financial crisis is that it exposes the political, structural and financial weaknesses of an economy. It explores efficiency in the financial market, transparency and accountability of new or reformed organizations, opportunity for creating new jobs and technologies, sufficient fund for investment in R\&D innovation and education.

During the financial crisis period, the extent of sufferance of an economy shows its weaknesses. When rest of the world gets disturbed and capital flows and liquidity shrinks, there is bound to be spillovers not just on India but all over the world. Regulators are trying to assess the situation and taking steps to insulate their economies from the shock. The fine fact that we have not been affected shows the merit of proceeding slowly. We have been reforming very slowly and steady pace of reforms has some advantage and we should continue with that pace. Our country pursued economic reforms in a calibrated manner and escaped the fallout of global financial crisis. So the expose of weaknesses will definitely help India's fast growing economy in the long run.

\section{Cost stabilization in real estate market.}

Both the builders' association Confederation of Real Estate Developers Association of India (CREDAI) and National Real Estate Development Council (NREDC) have appealed the members to slash prices of their properties. Builders feel that slashing down prices will encourage buyers and restore confidence. This enables middle-class families to think of having their own homes which had become a distant dream because of unrealistic rise in real estate properties. By developing middle-class families it is for sure that Indian economy will be affected positively in long run.

\section{Rationalization of Salary Structure in IT Industry} This financial crisis has a positive impact on the IT industry. This sector has seen an unmatched rise in salaries and increments. But with this financial crisis this unusual hike came under control as no economy can afford $25 \%$ to $30 \%$ salary hike per industry per annum. So now IT industry slowdown will ensure better quality of work and also prevent attrition. Today the IT professional have to think twice before changing their jobs. Along with it funds spent on recruitment, training and development and retention of man power will come down considerably. Earlier the scene was totally different. Because of such high growth rate of salary structure, IT professionals were changing jobs frequently which impacts adversely the job culture of the industry particularly. It also affected the overall productivity of the industry. But now the scene is reverse in nature. As a result of this financial crisis professionals not only think twice before changing the job but also ready to work more with the same salary with the objective to keep his job secure. This would definitely help in the improvement of this sector as well as the productivity of the IT industry.

\section{Performance Appraisal is gaining ground}

Earlier as there were many job opportunities available for the people; the role of performance appraisal was less. Every year, thousands of businesses were losing millions in revenue due to inefficient employees. Now as this financial crisis arises everyone is trying to save his job. Because of the changed job environment, emerged from the global financial crisis use of Performance Appraisal is gaining its ground day by day. As a result, everyone is ready to give his $100 \%$ to his job. Fear of losing the job improves the performance of the employees as a whole.

\section{RECENT GLOBAL MELTDOWN AND ITS IMPACT:}

Today, India is much more integrated with the world economy through both the current and capital accounts. The down turn that appears to have begun in the USA in September, 2008 have negative impact on Indian economy. The most immediate effect of this global financial crisis on India is an out flow of foreign institutional investment (FII) from the equity market. This withdrawal by the FIIs led to a steep depreciation of the rupee. The banking and nonbanking financial institutions have been suffering losses. The recession generated the financial crisis in USA and other developed economies have adversely affected India's exports of software and IT services. For fighting this crisis, government responded through its monetary policy by pumping the liquidity into the system rather than using effective fiscal policy i.e. public expenditure and investment to face 
the recession. No doubt, government has introduced three fiscal stimulus packages for stimulating demand in the economy but it is not sufficient, the larger government expenditure should be oriented towards agriculture and infrastructure. The present paper is an attempt to analyze the impact of recent global financial meltdown on Indian economy. The paper is divided into three sections. In the first introductory section, we have discussed the features of recent global financial meltdown. The section two, deals with the impact of this crisis on Indian economy. Conclusion and suggestions have been given in the third section.

\section{THE MODI GOVERMENT AND THE CHANGES IN ECONOMY:}

Prime Minister Narendra Modi is less than ten days away from completing action-packed three years at South Block. This month on 26 May, the Modi government will enter into fourth year of its five-year term.

Prime Minister Modi promised many economic reforms including ease of doing business, inflation control, fiscal deficit, trade deficit, job creation, manufacturing revival - that seems to have been delivered with the exception of job creation on which India has, so far, failed to perform as expected. Whatever may be the reason behind falling job creation and slow down in manufacturing industry, the Prime Minister has seemingly tried to address these two issues by introducing several key initiatives such as 'Make in India', 'Skill India', 'Start-up India'. Also, the Prime Minister last year on November 8 demonetised large currency notes which was later termed 'the single most economic reform in the history of independent India'.

\section{Goods and Services Tax:}

The GST bill, which is scheduled to be effective from July 1, is the biggest tax reform being undertaken since Independence. It will subsume all indirect taxes to create one rate and integrate the country into a single market. Once the GST is in force, it will replace at least 17 state and federal taxes and bring them under single unified tax structure.GST is a comprehensive indirect tax on manufacture, sale and consumption of goods and services throughout India to replace taxes levied by the central and state governments. It is expected to bring about a qualitative change in the tax system by redistributing the burden of taxation equitably between manufacturing and services. While officials are busy in laying down the guidelines for effective GST regime, the International Monetary Fund has already appreciated India's effort to reform country's taxation system. "The government has made significant progress on important economic reforms that will support strong and sustainable growth going forward," IMF Deputy Managing Director Tao Zhang said.

\section{Demonetisation}

Last year on November 8, the Prime Minister scrapped old Rs 500 and Rs 1,000 notes to what he called a step to root-out black money and fake currency in the system. Six months later, it was noticed that the move couldn't achieve the desired results as fake currencies were still running and corruption was still rampant. However, the government succeeded in profiling the people by getting to know the differences between actual flow of money and the undeclared money. Recently,it was reported that India has more car buyers than the taxpayers in the country.In last assessment year, there were only 5.5 lakh people, out of the 3.65 crore individuals who filed returns, paid income tax of more than Rs 5 lakh and accounted for 57 per cent of the total tax collection. This essentially means that only 1.5 per cent of those filing tax returns (3.65 crore) were contributing to 57 per cent of tax kitty. The Prime Minister wanted to address this issue by bringing the unaccounted money into banking channel. While many top-notch economists were divided over its impact on the economy, former UIDAI/Chairman Nandan Nilekani hailed Modi's demonetisaion move and said that it would see a massive activation of digitisation of financial services in the country. He also explained as to how India's over 80 per cent work force will come into formal channel, he said: "The more important thing is when the economy becomes formal, when everybody's financial transactions are digitised...India is going to go from data poor to data rich and that will make it more and more difficult for people to do dishonest things or to be outside the system. You will reduce the amount of black money in the system."

\section{Jan Dhan Accounts:}

It was 15 August 2014 when Prime Minister Narendra Modi launched India's biggest ever financial inclusion drive. PM Modi launched his first flagship programme called Pradhan Mantri Jan-Dhan Yojana which was country's National Mission for financial inclusion to ensure access to financial services, namely savings accounts, remittance, credit, 
insurance, pension in an affordable manner. Prime Minister's move was to provide access to formal banking services to more than 15 per cent of the unbanked population in the country. It helped Prime Minister Modi re-establish his image as the leader of masses. Jan Dhan Yojna was not just about banking but also about several other benefits that the Prime Minister Modi offered with the accounts.

Under the scheme, if a person holds an account for more than six months s/he is allowed an overdraft of up to Rs 5,000. Last year, the ET reported that over 19 lakh account holders had already availed an overdraft amounting to Rs 256 crore. Jan Dhan accounts holders are also able to claim accidental insurance cover of Rs 1 lakh. The scheme also provides life cover of Rs. 30,000 payable on death of the beneficiary. Prime Minister Modi tapped country's over 15 per cent population with just one economic policy. So far, over 27.84 crore accounts have been opened under Jan Dhan Yojna.

\section{Affordable Housing:}

After promising banking for all, Prime Minister Narendra Modi launched another flagship housing scheme 'Pradhan Mantri Gramin Awas Yojna' with the aim of providing 'Housing For All' by 2022. The scheme was designed entirely for the rural masses. The ambitious scheme aimed to provide affordable houses to 4 crore people living below the poverty line. Under the new rural housing scheme, the central government will provide a financial assistance of Rs 120000/- for constructing the home. An additional assistance of Rs 12000 would be provided for construction of toilets in households. Pradhan Mantri Awas Yojna says that "By the time the Nation completes 75 years of its Independence, Pradhan Mantri Awas Yojna will bring a 'Pucca house' for every family in urban cities with water connection, toilet facilities, $24 \times 7$ electricity supply and complete access." In Uttar Pradesh alone there are '1.5 crore people who don't have houses'.
5. Deen Dayal Upadhyaya Gram Jyoti Yojana Gram Jyoti Yojana was launched to ensure round the clock electricity supply to farmers and rural households. The scheme was kick-started by the Prime Minister on 25 July 2015. The programme was expected to initiate much awaited reforms in the rural areas. During his Independence Day speech in 2015, the Prime Minister had announced that all of the country's villages would be electrified in 1,000 days and that by December 2018; all Indian citizens would have access to electricity.

"At the time when the NDA government came to power, there were 18,452 un-electrified villages. Out of these, we have electrified 12,022 villages under the Deen Dayal Upadhyaya Gram Jyoti Yojna (DDUGJY). The ministry is trying its best to complete the target by 1 May 2018," The Sunday Guardian quoted a ministry official as saying.

\section{PM Ujjwala Yojana}

Last year on May 1, Prime Minister Narendra Modi launched an ambitious social welfare scheme Pradhan Mantri Ujjwala Yojana - with the aim of providing 5 crore LPG connections to women below the poverty line across the country. The scheme was aimed at replacing the unclean cooking fuels mostly used in the rural India with the clean and more efficient LPG Gas.

Prime Minister Modi's pledge to provide cooking gas cylinders to every household has helped India to become the world's second-largest importer of liquefied petroleum gas or LPG. Earlier Bloomberg reported that India's import of LPG, mostly used as cooking fuel, increased 23 per cent during the financial year that ended March 31 to 11 million tons. India replaced Japan from the second position whose imports slipped 3.2 per cent during the same period to 10.6 million tons. 